\title{
Conjunctival tumors in children: histopathologic diagnosis in 165 cases
}

\section{Tumores conjuntival em crianças: diagnóstico histopatológico em 165 casos}

Martin A. Zimmermann-Paiz ${ }^{1}$, Juan Carlos García de la Riva ${ }^{2}$

\begin{abstract}
Purpose: Conjunctival tissue tumors have a varied presentation, and few series studies on pediatric patients have been published. The objective of this paper is to report the histopathologic diagnoses (spanning over 1988-2013) of conjunctival tumors in children younger than 14 years.

Methods: We conducted a retrospective, descriptive, and observational study by reviewing the database of all children in whom a conjunctival tumor was surgically removed at Hospital de Ojos y Oídos "Dr. Rodolfo Robles V.," Benemérito Comité Pro Ciegos y Sordos de Guatemala. The data pertaining to gender, age, and histopathologic diagnosis of all cases was collected. The same ocular pathologist made all diagnoses.

Results: One hundred sixty-five cases were found, with a mean age of 7.88 years, being 91 (55.15\%) male subjects. Melanocytic lesions were the most common tumors found (30.91\% of cases), with only one case $(0.60 \%)$ being malignant.

Conclusions: Melanocytic lesions were the most common tumors found, and of all the cases, only one was malignant; this was in a patient with xeroderma pigmentosum. These findings are consistent with those reported in other studies regarding the frequencies of the histopathology of conjunctival tumors in the pediatric population.
\end{abstract}

Keywords: Conjunctival neoplasms/diagnosis; Conjunctival neoplasms/pathology; Child

\section{RESUMO}

Objetivo: Tumores do tecido conjuntival tem uma apresentação variada. Poucas séries de pacientes pediátricos foram publicadas. O objetivo deste trabalho é apresentar os diagnósticos histopatológicos de tumores conjuntivais em crianças com menos de 14 anos de idade, obtidas durante um período de 25 anos.

Métodos: Estudo retrospectivo, descritivo e observacional foi realizado. Nós revisamos o banco de dados de todas as crianças em quem um tumor conjuntival foi removido cirurgicamente no Hospital de Ojos y oidos "Dr. Rodolfo Robles V.," Benemérito Comité Pro Ciegos y Sordos de Guatemala. Sexo, idade e diagnóstico histopatológico de todos os casos foram compilados. O mesmo patologista ocular fez todos os diagnósticos.

Resultados: Cento e sessenta e cinco casos foram encontrados, com média de 7,88 anos, sendo 91 (55,15\%) do sexo masculino. Lesões melanocíticas foram as mais frequentes (30,91\% dos casos). Apenas um caso $(0,60 \%)$ era maligno.

Conclusões: Lesões melanocíticas foram as mais frequentes. Do total, apenas uma lesão era maligna, o que correspondeu a um paciente com xeroderma pigmentoso. Estes resultados são consistentes com o relatado em outros estudos quanto à frequência de diagnóstico histopatológico de tumores da conjuntiva na população pediátrica.

Descritores: Neoplasias da túnica conjuntiva/diagnóstico; Neoplasias da túnica conjuntiva/patologia; Criança

\section{INTRODUCTION}

The conjunctiva is derived from the surface ectoderm of the optic vesicle and neuro ectoderm. It comprises epithelium (stratified squamous and columnar) and stroma (fibrovascular connective tissue $)^{(1,2)}$. Conjunctival tumors (Figures 1 and 2) can arise from any of the component cells; therefore, their presentation varies as either benign or malignant. Few series of studies on pediatric patients have been published, and the epidemiological characteristics vary with age ${ }^{(3-6)}$ Cunha et al. reported the histopathology of 282 consecutive, clinically diagnosed epibulbar tumors excised from children. The most common tumors were melanocytic (23\%), choristomatous (22\%), and benign epithelial (10\%) tumors ${ }^{(3)}$. In another case series, Elsas et al. reported 302 cases of epibulbar tumors in children, comprising 33\% choristomas, 29\% conjunctival nevi, 11\% epithelial inclusion cysts, 7\% papillomas, $6 \%$ pyogenic granulomas, and $5 \%$ granulomas ${ }^{(4)}$. Beby et al. described the clinicopathological characteristics of 42 conjunctival tumors that were surgically removed from children; $83 \%$ of the cases in this series were pigmented conjunctival nevi ${ }^{(5)}$. Further, in a clinical series of 262 pediatric patients, Shields et al. reported melanocytic tumors in $67 \%$ of the cases ${ }^{(6)}$.

The aim of this paper is to report the frequency and histopathologic diagnosis of conjunctival tumors that were surgically removed from children under 14 years of age from 1988 to 2013 at an eye care center from a developing country.

\section{METHODS}

We conducted a retrospective, descriptive, and observational study by reviewing the database of all pediatric patients under 14 years of age with a conjunctival tumor that was surgically removed from

Submitted for publication: January 2, 2015

Accepted for publication: August 23, 2015

${ }^{1}$ Unidad de Oftalmología pediátrica, Estrabismo y Neuro-Oftalmología, "Dra. Ana María Illescas Putzeys," Hospital de Ojos y Oídos "Dr. Rodolfo Robles V." Instituto de Ciencias de la Visión, Benemérito Comité Pro Ciegos y Sordos de Guatemala, Guatemala.

Unidad de patología ocular, Hospital de Ojos y Oídos "Dr. Rodolfo Robles V." Instituto de Ciencias

de la Visión, Benemérito Comité Pro Ciegos y Sordos de Guatemala.

Funding: No specific financial support was available for this study Disclosure of potential conflicts of interest: None.

Corresponding author: Dr. Martin A. Zimmermann-Paiz. Diagonal 21, 19-19 anillo periférico Zona 11 - Guatemala, Guatemala C.A. - E-mail: oftalmopedia@gmail.com 

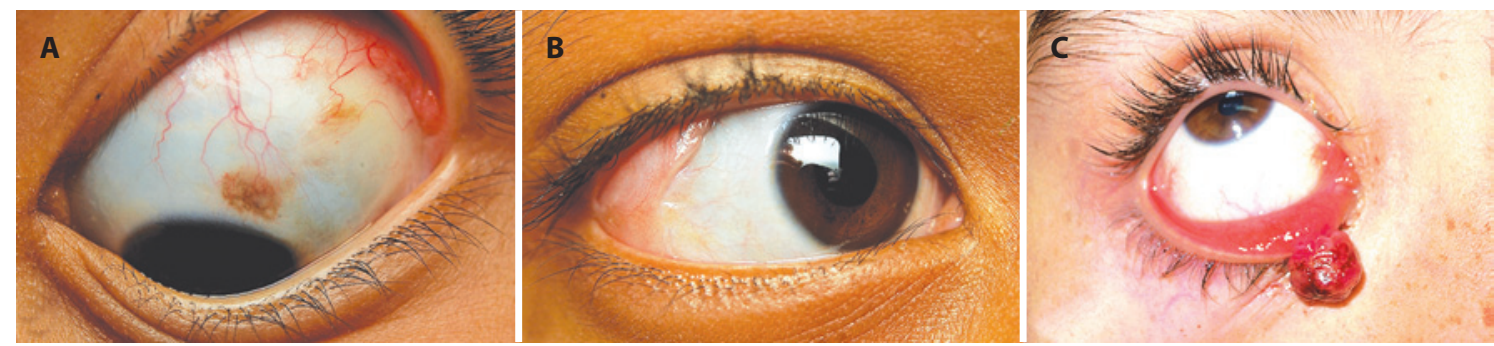

Figure 1. A) Pigmented lesion (nevi). B) Choristoma (epibulbar dermoid). C) Vascular lesion (pyogenic granuloma).
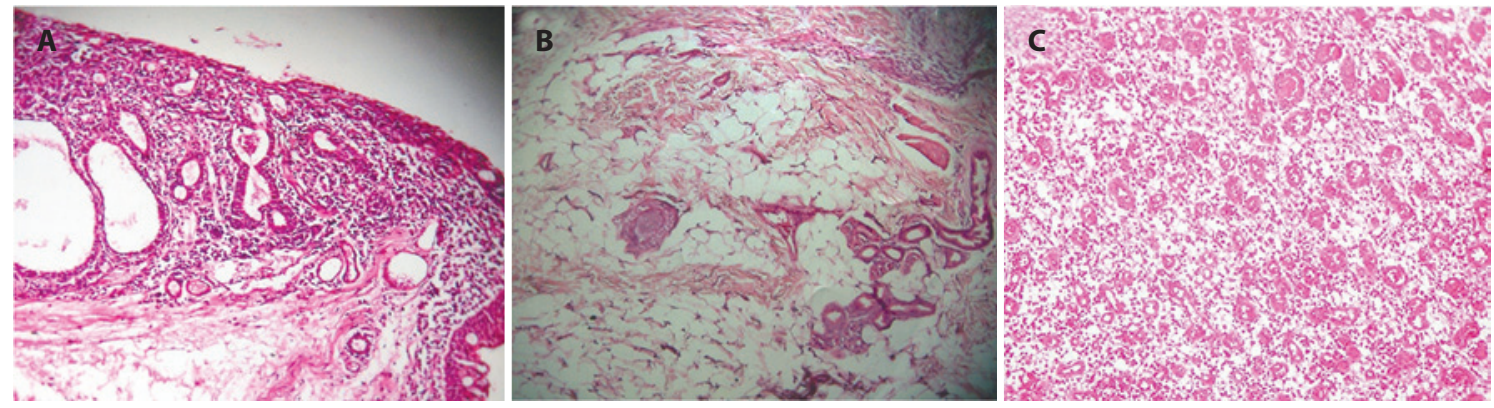

Figure 2. A) Pigmented lesion: conjunctival biopsy showing nevoid tissue with cystic degeneration in a prepubescent boy (40X). B) Choristoma: conjunctival tumor showing mature sebaceous tissue with hair shafts and glandular channels (40x). C) Vascular lesion: granulation tissue with chronic inflammatory cells, fibroblasts, and endothelial cells of budding capillaries. The typical arborizing pattern is not seen in this specimen (40X).

1988 to 2013 at Hospital de Ojos y Oídos "Dr. Rodolfo Robles V.," Benemérito Comité Pro Ciegos y Sordos de Guatemala. The data pertaining to gender, age, and histopathological diagnosis of all cases was obtained. All diagnoses were made by the same ocular pathologist and were classified based on the tissues of origin. The data were analyzed using the $\mathrm{EPI}-\mathrm{INFO}{ }^{\circledR}$ program (database and statistics software for public health professionals; 2014; Centers for Disease Control and Prevention, Atlanta, GA, USA), which was used to obtain descriptive statistics for this study population.

\section{RESULTS}

A total of 165 cases, 91 (55.15\%) male and 74 (44.85\%) female, were found. The age ranged from 7 months to 13 years, with a mean age of 7.88 years. The tumors were classified based on their tissue of origin, and included melanocytic, choristomatous, vascular, epithelial, lymphoid, and others. Table 1 summarizes the frequencies observed, depending on the type and histological diagnosis of the lesions. Melanocytic lesions were the most common (30.91\% of the total cases), of which 47 (92.15\%) were classified as benign, 4 (7.85\%) as borderline, and none as malignant; the most frequent histological diagnosis was conjunctival nevi (41.18\%). The most frequent histological diagnoses for the remainder of the tumor types were dermoid tumors $(38.89 \%)$ in the choristoma group, pyogenic granulomas $(77.78 \%)$ in the vascular group, and papillomas in the epithelial group (80.00\%). Among the epithelial lesions, 26 (86.66\%) were classified as benign, $3(10.00 \%)$ as borderline, and 1 (3.33\%) as malignant (in a patient with xeroderma pigmentosum). This lesion was the only malignancy found in the 165 cases (0.60\%). Moreover, $12.12 \%$ of the lesions did not fit into any of the categories, and were thus grouped as miscellaneous lesions.

\section{DISCUSSION}

The importance of determining the histopathological diagnosis and behavior of conjunctival tumors in children is primarily to establish the aggressiveness of the surgical approach. Indications for the removal of these lesions in children may be as varied as the suspicion of malignancy, purely functional disorders, or cosmesis, which is the most common. Our study shows that the histopathological diagnoses of patients from a referral hospital, which may have resulted in biased data, because tumor incidences may differ from those seen in clinical practice in the general population. In this series, melanocytic lesions were the most common (30.91\%), which is consistent with other reported series of patients in both children $(23-83 \%)^{(3-6)}$ and adults $(53 \%)^{(7)}$ Conjunctival nevi are the most common melanocytic tumors and are usually occur before 20 years of age. The intensity of the pigment increases in 5\% of these tumors, $7 \%$ grow in size with increasing age, and less than $1 \%$ become malignant. ${ }^{(6)}$. Management is usually expectant (measurement of the lesion and taking photographs for future comparisons), and if major changes are documented, surgical removal of the lesion must be considered ${ }^{(2,6)}$. Choristomatous lesions were the second most common. These consist of tissue that is not normally located in the area affected by the lesion $n^{(1,2,6)}$. These lesions are usually treated conservatively ${ }^{(2,6)}$. In vascular lesions, the most common histopathological diagnosis is pyogenic granuloma, a fibro- 
Table 1. Frequencies of conjunctival tissue tumors found in 165 children in terms of the type and histological diagnosis of the lesion

\begin{tabular}{|c|c|c|}
\hline Histopathological diagnosis & $\mathbf{N}(\%)$ & $\%$ of total cases \\
\hline \multicolumn{3}{|l|}{ Melanocytic } \\
\hline Conjunctival nevus & $21(41.18)$ & 12.72 \\
\hline Single nevus & $14(27.45)$ & 8.48 \\
\hline Compound nevus & $13(25.49)$ & 7.88 \\
\hline Conjunctival nevus with atypia & $2(3.92)$ & 1.21 \\
\hline Benign acquired melanosis & $1(1.96)$ & 0.60 \\
\hline Total & $51(100.00)$ & 30.91 \\
\hline \multicolumn{3}{|l|}{ Choristomas } \\
\hline Dermoid tumor & $14(38.89)$ & 8.48 \\
\hline Epidermoid cyst & $12(33.33)$ & 7.27 \\
\hline Dermolipoma & $9(25.00)$ & 5.45 \\
\hline Ectopic striated muscle & $1(2.78)$ & 0.60 \\
\hline Total & $36(100.00)$ & 21.82 \\
\hline \multicolumn{3}{|l|}{ Vascular } \\
\hline Pyogenic granuloma & $21(77.78)$ & 12.72 \\
\hline Capillary hemangioma & $5(18.52)$ & 3.03 \\
\hline Cavernous hemangioma & $1(3.70)$ & 0.60 \\
\hline Total & $27(100.00)$ & 16.36 \\
\hline \multicolumn{3}{|l|}{ Epithelial } \\
\hline Papilloma & $20(80.00)$ & 12.12 \\
\hline Inclusion cyst & $5(20.00)$ & 3.03 \\
\hline Acanthosis & $3(12.00)$ & 3.03 \\
\hline Squamous carcinoma & $1(4.00)$ & 0.60 \\
\hline Pseudoepitheliomatous hyperplasia & $1(4.00)$ & 0.60 \\
\hline Total & $30(100.00)$ & 18.18 \\
\hline \multicolumn{3}{|l|}{ Lymphoid } \\
\hline Atypical lymphoid hyperplasia & $1(100.00)$ & 0.60 \\
\hline Total & $1(100.00)$ & 0.61 \\
\hline \multicolumn{3}{|l|}{ Other } \\
\hline Elastotic degeneration & $5(20.00)$ & 3.03 \\
\hline Vernal conjunctivitis & $2(8.00)$ & 1.21 \\
\hline nonspecific inflammatory reaction & $2(8.00)$ & 1.21 \\
\hline $\begin{array}{l}\text { Granulation tissue (part of wound repair } \\
\text { processes) }\end{array}$ & $2(8.00)$ & 1.21 \\
\hline Foreign body & $1(4.00)$ & 0.60 \\
\hline Subconjunctival epidermization & $1(4.00)$ & 0.60 \\
\hline Granuloma (indeterminate) & $1(4.00)$ & 0.60 \\
\hline Foreign body granuloma & $1(4.00)$ & 0.60 \\
\hline Parasitic cyst & $1(4.00)$ & 0.60 \\
\hline Valve remaining fibrosis & $1(4.00)$ & 0.60 \\
\hline Insufficient sample & $2(8.00)$ & 1.21 \\
\hline Total & $20(100.00)$ & 12.12 \\
\hline
\end{tabular}

vascular proliferation in response to a previous insultt(2,6). In many cases, they are secondary to inflammatory processes, either postsurgical or from trauma. These usually respond well to steroid therapy; however, in some cases, surgical removal of the lesion is necessary because of the size and functional problems incurred.

The most common epithelial lesions are papillomas. These benign tumors are generally associated with papillomavirus infection ${ }^{(1,2,6)}$ and are small in children and may present as multiple lesions. As these cases are usually symptomatic, we recommend surgical removal of the lesion; however, it should be noted that spontaneous remission occurs for some of these lesions.

The main difference between conjunctival tissue tumors in pediatric and adult populations is that the incidence of malignant lesions in the former was less than 1\% in the present study (one case in a patient diagnosed with xeroderma pigmentosum), which is consistent with the literature ${ }^{(2-8)}$. Patients with immunosuppression, such as those having recently undergone a transplant or having an HIV infection or disorders of DNA repair, such as xeroderma pigmentosum, should be carefully followed up because malignant epithelial lesions are more frequently found in these patients ${ }^{(6)}$.

\section{CONCLUSIONS}

Melanocytic lesions were the most frequently found conjunctival tissue tumors in the 165 pediatric patients (30.91\% of the total cases) in the present study. Of all cases, only one (0.60\%) was a malignant lesion, in a patient with xeroderma pigmentosum. These findings are consistent with those reported in other studies regarding the frequency of histopathological diagnoses of conjunctival tumors in the pediatric population.

\section{REFERENCES}

1. Taylor D, Hoyt CS. Pediatric ophthalmology and strabismus. $3^{\text {rd }}$ ed. Edinburg: Elsevier Saunders; 2005.

2. Shields $\mathrm{Cl}$, Shields JA. Tumors of the conjunctiva and cornea. Surv Ophthalmol. 2004; 49(1):3-24.

3. Cunha RP, Cunha MC, Shields JA. Epibulbar tumors in children: a survey of 282 biopsies. J Pediatr Ophthalmol Strabismus. 1987;24(5):249-54.

4. Elsas FJ, Green WR. Epibulbar tumors in childhood. Am J Ophthalmol. 1975;79(6):1001-7.

5. Beby F, Kodjikian L, Roche O, Bouvier R, Donate D, Guerillon F, et al. Conjunctival Tumors in children. A histopathologic study of 42 cases. J Fr Ophthalmol. 2005;28(8): 817-23.

6. Shields CL, Shields JA. Conjunctival tumors in children. Curr Opin Ophthalmol. 2007; 18(5):351-60.

7. Shields CL, Demirci H, Karatza E, Shields JA. Clinical survey of 1643 melanocytic and nonmelanocytic conjunctival tumors. Ophthalmology. 2004;111(9):1747-54.

8. Reddy SC, Sarma CS, Ramana Rao W, Banerjea S. Tumor and cysts of conjunctiva - A study of 175 cases. Indian J Ophthalmol. 1983:31(5):658-60. 